\title{
Verification of methods for calculating the gas volume fraction in the vertical descending flow of two-phase gas-liquid mixtures
}

Krystian CZERNEK, Patryk OKON

DOI: $10.30464 /$ jmee.2018.2.4.293

Cite this article as:

Czernek K., Okoń P. Verification of methods for calculating the gas volume fraction in the vertical descending flow of two-phase gas-liquid mixtures. Journal of Mechanical and Energy Engineering, Vol. 2(42), No. 4, 2018, pp. 293300.

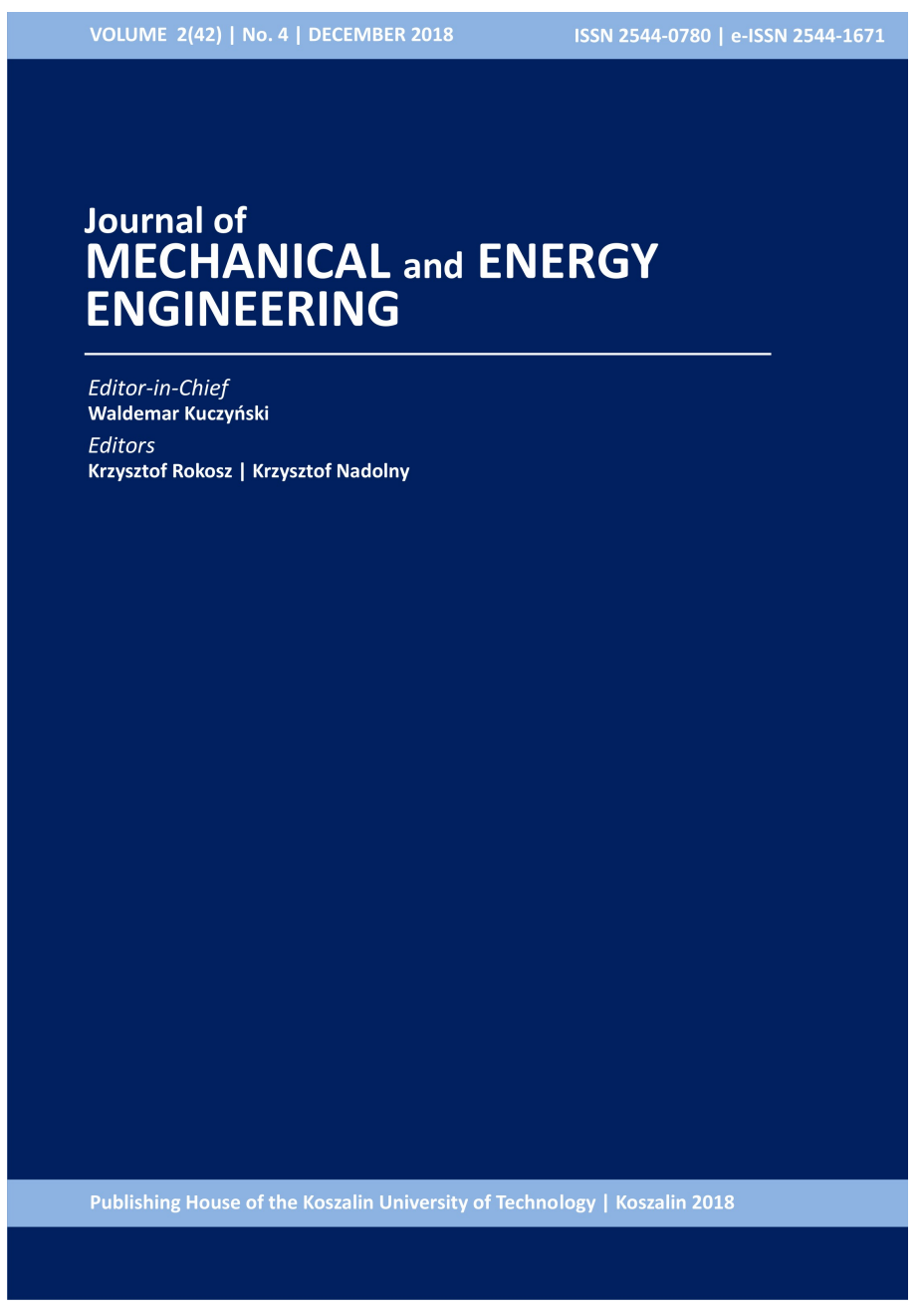

Journal of Mechanical and Energy Engineering

Website: jmee.tu.koszalin.pl

ISSN (Print): 2544-0780

ISSN (Online): 2544-1671

Volume: 2(42)

Number: 4

Year: 2018

Pages: 293-300

Article Info:

Received 7 November 2018

Accepted 12 December 2018

\section{Open Access}

This article is distributed under the terms of the Creative Commons Attribution 4.0 (CC BY 4.0) International License (http://creativecommons.org/licenses/by/4.0/), which permits unrestricted use, distribution, and reproduction in any medium, provided you give appropriate credit to the original author(s) and the source, provide a link to the Creative Commons license, and indicate if changes were made. 


\title{
VERIFICATION OF METHODS FOR CALCULATING THE GAS VOLUME FRACTION IN THE VERTICAL DESCENDING FLOW OF TWO-PHASE GAS-LIQUID MIXTURES
}

\author{
Krystian CZERNEK $^{1 *}$, Patryk OKOŃ ${ }^{1}$ \\ ${ }^{1 *}$ Department of Process Engineering, Faculty of Mechanical Engineering, Opole University \\ of Technology, St. Mikołajczyka 5, 45-271 Opole, Poland, e-mail: k.czernek@po.edu.pl, \\ patryk.okon@doktorant.po.edu.pl
}

(Received 7 November 2018, Accepted 12 December 2018)

\begin{abstract}
The paper presents the results of research on the vertical falling flow and their analysis. Methods for calculating the gas volume fraction, which are characterized by high accuracy, and are often proposed in the literature. Their accuracy was presented, as well as the methods with the highest computational usefulness when designing devices in which two-phase gas - liquid flow is used.
\end{abstract}

Keywords: two phase flow gas-liquid, volume share of gas, hydrodynamic flow

\section{INTRODUCTION}

Two-phase flow occurs in many branches of industry. It is also used in many technological processes such as sedimentation, fluidization, filtration, etc. For this reason, two-phase flows are the goal of many tests and analyzes. In the two-phase flow there is simultaneous flow of the continuous phase, which is a gas or liquid and a dispersed phase, where it is a solid, liquid or gas.

A characteristic feature of two-phase flow is the phase separation boundary, which forms and changes during movement. The individual phases of the twophase mixture should be able to be separated mechanically by, e.g. centrifugation, filtration or percolation.

The basic parameters that characterize two-phase flow are:

- two-phase flow resistance,

- two-phase flow structure,

- volume fraction of one of the phases.

Determining the volume fraction of the gas is very complicated due to the density of the flowing mixture, which is related to the value of the gas volume fraction $R_{G}$ or the value of the volume fraction of the liquid 1$R_{G}$. The value of the volume fraction is influenced by, inter alia, occurrence of phase slip phenomenon, which should be taken into mind that both phases flow at different velocity.

If no phase slip is taken into account, the volume fraction takes the form (1):

$$
R_{g}=\frac{1}{1+\frac{1-x}{x} \frac{\rho_{g}}{\rho_{c}}}
$$

However, the volume share, taking into account the phase slip, generally takes the form (2):

$$
R_{g}=\frac{1}{1+\frac{1-x}{x} \frac{\rho_{g}}{\rho_{c}} \frac{w_{g}}{w_{c}}}
$$

where:

$\rho_{g}-$ gas density, $\mathrm{kg} / \mathrm{m}^{3}$,

$\rho_{c}$ - liquid density, $\mathrm{kg} / \mathrm{m}^{3}$,

$w_{g}-$ gas velocity, $\mathrm{m} / \mathrm{s}$,

$w_{c}$ - liquid velocity, $\mathrm{m} / \mathrm{s}$.

In the literature various calculation models are presented: non-slip models, where value $w_{g} / w_{c}=1$ and slip models, in which $w_{g} / w_{c}>1$. The calculation models of the average value of gas volume fraction presented by the authors often differ not only in the form itself, but also in the ranges of use as well as the types of two-phase mixtures. 
Tab. 1. General characteristics of grinding conditions

\begin{tabular}{|c|c|}
\hline Method & Characteristics of the method \\
\hline Armand & $\begin{array}{c}R_{g}=1-\frac{4+\frac{4}{7} m}{5+m\left(\frac{\varepsilon}{1-\varepsilon}+\frac{8}{7}\right)} \\
m=4 \operatorname{Re}_{c, 0}^{\frac{1}{8}}\left(\frac{\rho_{g}}{\rho_{c}}\right)^{0,5} \\
{\left[0,69+(1-\varepsilon)\left(4+21,9 \sqrt{F r_{c, 0}}\right)\right]}\end{array}$ \\
\hline Bankoff & $R_{g}=\varepsilon\left(0,71+2,35 \frac{\rho_{c}}{\rho_{g}}\right)$ \\
\hline Baroczy & $R_{g}=\frac{1}{1+\left(\frac{1-x}{x}\right)^{0,74}\left(\frac{\rho_{g}}{\rho_{c}}\right)^{0,65}\left(\frac{\eta_{c}}{\eta_{g}}\right)^{0,13}}$ \\
\hline Chen & $R_{g}=\frac{1}{1+0,18\left(\frac{1-x}{x}\right)^{0,6}\left(\frac{\rho_{g}}{\rho_{c}}\right)^{0,33}\left(\frac{\eta_{c}}{\eta_{g}}\right)^{0,07}}$ \\
\hline Harrison & $R_{g}=\frac{1}{1+\left(\frac{1-x}{x}\right)^{0,8}\left(\frac{\rho_{g}}{\rho_{c}}\right)^{0,515}}$ \\
\hline $\begin{array}{l}\text { Locharta- } \\
\text { Martinelli }\end{array}$ & $R_{g}=\frac{1}{1+0,28\left(\frac{1-x}{x}\right)^{0,64}\left(\frac{\rho_{g}}{\rho_{c}}\right)^{0,36}\left(\frac{\eta_{c}}{\eta_{g}}\right)^{0,07}}$ \\
\hline $\begin{array}{l}\text { Spedding, } \\
\text { Chen }\end{array}$ & $R_{g}=\frac{1}{1+\left(\frac{1-x}{x}\right)^{0,65}\left(\frac{\rho_{g}}{\rho_{c}}\right)^{0,65}}$ \\
\hline Stomm & $\begin{array}{c}R_{g}=1-\frac{\varepsilon_{g}^{2}-x^{2}}{2\left[\ln \left(\frac{1-x}{1-\varepsilon_{g}}\right)-\left(\varepsilon_{g}-x\right)\right]} \\
x=\frac{w_{g} \rho_{g}}{w_{g} \rho_{g}+w_{c} \rho_{c}} ; \varepsilon_{g}==\frac{w_{g}}{w_{g}+w_{c}}\end{array}$ \\
\hline Thom & $\begin{array}{c}R_{g}=\frac{\gamma x}{1+x(\gamma-1)} \\
\gamma=W^{1,6} \\
W=\left(\frac{\rho_{c}}{\rho_{g}}\right)^{0,555}\left(\frac{\eta_{g}}{\eta_{c}}\right)^{0,111}\end{array}$ \\
\hline $\begin{array}{l}\text { Turner and } \\
\text { Wallis }\end{array}$ & $R_{g}=\frac{1}{1+\left(\frac{1-x}{x}\right)^{0,72}\left(\frac{\rho_{g}}{\rho_{c}}\right)^{0,40}\left(\frac{\eta_{c}}{\eta_{g}}\right)^{0,08}}$ \\
\hline Zivi & $R_{g}=\frac{1}{1+\left(\frac{1-x}{x}\right)\left(\frac{\rho_{g}}{\rho_{c}}\right)^{0,67}}$ \\
\hline $\begin{array}{l}\text { Zuber- } \\
\text { Findlay }\end{array}$ & $\begin{array}{c}R_{g}=\frac{x}{\rho_{g}}\left[C_{0}\left(\frac{x}{\rho_{g}}+\frac{1-x}{\rho_{c}}\right)+\frac{V_{0}}{g_{2 F}}\right]^{-1} \\
V_{0}=V^{*}\left[\frac{\check{\mathrm{g}} \sigma\left(\rho_{c}-\rho_{g}\right.}{\rho_{c}^{2}}\right]^{2} \\
C_{0}=1,2 ; V^{*}=1,14\end{array}$ \\
\hline
\end{tabular}

\section{RESULTS AND DISCUSSION}

Based on the literature review [1-16, 18-28], regarding the methods for determining the volume fraction of gas in two-phase flows, it was noticed that many methods have particular ranges of their use and various forms of equations that do not allow for a direct comparison of individual calculation methods. An attempt was made to assess the applicability of selected calculation methods for typical two-phase systems:

- water-air,

- ethanol-air,

- glycerin-air.

The experimental data used for the analysis of calculation methods was taken from the dataset of Department Process Engineering of University of Technology in Opole [17]. The tests were carried out in vertical cannels with a diameter of $20,24,25,32$, 44 and $50 \mathrm{~mm}$, with co-current descending two-phase gas and liquid flow. The range of apparent gas velocities $\left(w_{g}\right)$ was $0.01-75 \mathrm{~m} / \mathrm{s}$ and the liquid $\left(w_{c}\right)$ $0.01-2 \mathrm{~m} / \mathrm{s}$. The preliminary assessment allowed for the selection of 12 calculation methods (Tab. 1), determining the gas volume fraction characterizing the interfacial slip (e.g. the Lockhart-Martinnelli model) and the different validity of using only in narrow ranges or for selected two-phase mixtures, e.g. the Zuber-Findlay method.

The assessment of the accuracy of individual methods and their usefulness in determining the gas volume participation consisted in determining the characteristic statistical parameters including the determination of the mean value of the relative error $\delta R_{g}$ as well as the mean value of the absolute error $\left|\delta R_{g}\right|$ (Tab. 2).

Tab. 2. Statistical evaluation of gas volume participation

\begin{tabular}{|c|c|c|c|}
\hline \multirow[t]{2}{*}{ Data } & \multirow[t]{2}{*}{ Method } & \multicolumn{2}{|c|}{$\begin{array}{l}\text { Value of statistical } \\
\text { values }\end{array}$} \\
\hline & & $\delta R_{g} \%$ & $\left|\delta R_{g}\right| \%$ \\
\hline \multirow{12}{*}{$\begin{array}{l}\text { Dawydow } \\
\text { ethanol-air }\end{array}$} & Armand & 28.92 & 28.92 \\
\hline & Bankoff & 42.65 & 42.65 \\
\hline & Baroczy & 59.68 & 59.68 \\
\hline & Chen & 19.36 & 23.43 \\
\hline & Harrison & 79.41 & 79.41 \\
\hline & $\begin{array}{l}\text { Lockhart- } \\
\text { Martinelli }\end{array}$ & 45.92 & 45.92 \\
\hline & $\begin{array}{l}\text { Spedding, } \\
\text { Chen }\end{array}$ & 44.14 & 44.14 \\
\hline & Stomm & 44.81 & 44.81 \\
\hline & Thom & 74.20 & 74.20 \\
\hline & Turner, Wallis & 87.14 & 87.14 \\
\hline & Zivi & 86.02 & 86.02 \\
\hline & Zuber-Findlay & 36.66 & 36.66 \\
\hline
\end{tabular}


Tab. 2. Statistical evaluation of gas volume participation - contiuned

\begin{tabular}{|c|c|c|c|c|}
\hline \multirow[t]{2}{*}{ Data } & \multirow[t]{2}{*}{ Method } & \multicolumn{3}{|c|}{$\begin{array}{l}\text { Value of statistical } \\
\text { values }\end{array}$} \\
\hline & & $\delta R_{g} \%$ & $\left|\delta R_{g}\right|$ & $\%$ \\
\hline \multirow{12}{*}{$\begin{array}{l}\text { Dawydow } \\
\text { glycerin- air }\end{array}$} & Armand & 23.68 & 29.28 & \\
\hline & Bankoff & 42.58 & 42.58 & \\
\hline & Baroczy & 82.11 & 82.11 & \\
\hline & Chen & 41.96 & 42.24 & \\
\hline & Harrison & 81.50 & 81.50 & \\
\hline & $\begin{array}{l}\text { Lockhart- } \\
\text { Martinelli }\end{array}$ & 64.44 & 64.44 & \\
\hline & $\begin{array}{l}\text { Spedding, } \\
\text { Chen }\end{array}$ & 37.61 & 38.05 & \\
\hline & Stomm & 39.95 & 39.95 & \\
\hline & Thom & 92.85 & 92.85 & \\
\hline & Turner, Wallis & 93.26 & 93.26 & \\
\hline & Zivi & 88.67 & 88.67 & \\
\hline & Zuber-Findlay & 37.45 & 37.45 & \\
\hline \multirow{12}{*}{$\begin{array}{l}\text { Dawydow } \\
\text { water-air }\end{array}$} & Armand & 30.06 & 30.28 & \\
\hline & Bankoff & 44.36 & 44.36 & \\
\hline & Baroczy & 60.23 & 60.23 & \\
\hline & Chen & 20.82 & 28.37 & \\
\hline & Harrison & 81.06 & 81.06 & \\
\hline & $\begin{array}{l}\text { Lockhart- } \\
\text { Martinelli }\end{array}$ & 47.89 & 47.89 & \\
\hline & $\begin{array}{l}\text { Spedding, } \\
\text { Chen }\end{array}$ & 44.22 & 44.30 & \\
\hline & Stomm & 45.26 & 45.26 & \\
\hline & Thom & 75.24 & 75.24 & \\
\hline & Turne, Wallis & 88.03 & 88.03 & \\
\hline & Zivi & 87.55 & 87.55 & \\
\hline & Zuber-Findlay & 39.30 & 39.30 & \\
\hline \multirow{12}{*}{$\begin{array}{l}\text { Oshinowo } \\
\text { water-air }\end{array}$} & Armand & -12.78 & 19.09 & \\
\hline & Bankoff & 2.95 & 27.68 & \\
\hline & Baroczy & 0.42 & 12.48 & \\
\hline & Chen & -18.77 & 20.83 & \\
\hline & Harrison & 19.24 & 21.70 & \\
\hline & $\begin{array}{l}\text { Lockhart- } \\
\text { Martinelli }\end{array}$ & -3.15 & 15.10 & \\
\hline & $\begin{array}{l}\text { Spedding, } \\
\text { Chen }\end{array}$ & -6.61 & 14.74 & \\
\hline & Stomm & 59.59 & 79.15 & \\
\hline & Thom & 1.78 & 13.13 & \\
\hline & Turner, Wallis & 37.24 & 37.24 & \\
\hline & Zivi & 18.01 & 19.75 & \\
\hline & Zuber-Findlay & -3.79 & 20.69 & \\
\hline
\end{tabular}

\begin{tabular}{|c|c|c|c|}
\hline \multirow{12}{*}{$\begin{array}{l}\text { Oshinowo } \\
\text { glycerin- air }\end{array}$} & Armand & 16.16 & 16.40 \\
\hline & Bankoff & 22.46 & 22.46 \\
\hline & Baroczy & 14.09 & 15.06 \\
\hline & Chen & 7.09 & 8.46 \\
\hline & Harrison & 24.29 & 24.29 \\
\hline & $\begin{array}{l}\text { Lockhart- } \\
\text { Martinelli }\end{array}$ & 14.34 & 14.69 \\
\hline & $\begin{array}{l}\text { Spedding, } \\
\text { Chen }\end{array}$ & 10.19 & 11.18 \\
\hline & Stomm & 80.37 & 80.37 \\
\hline & Thom & 8.77 & 13.32 \\
\hline & Turner, Wallis & 44.46 & 44.46 \\
\hline & Zivi & 18.89 & 20.73 \\
\hline & Zuber-Findlay & 14.29 & 14.32 \\
\hline \multirow{12}{*}{$\begin{array}{l}\text { Lorenzi } \\
\text { water-air }\end{array}$} & Armand & -12.47 & 28.46 \\
\hline & Bankoff & 42.67 & 42.67 \\
\hline & Baroczy & 47.19 & 47.19 \\
\hline & Chen & -48.45 & 53.28 \\
\hline & Harrison & 78.84 & 78.84 \\
\hline & $\begin{array}{l}\text { Lockhart- } \\
\text { Martinelli }\end{array}$ & 15.15 & 30.71 \\
\hline & $\begin{array}{l}\text { Spedding, } \\
\text { Chen }\end{array}$ & 9.72 & 29.31 \\
\hline & Stomm & 27.02 & 27.47 \\
\hline & Thom & 79.87 & 79.87 \\
\hline & Turner, Wallis & 84.96 & 84.96 \\
\hline & Zivi & 90.41 & 90.41 \\
\hline & Zuber-Findlay & 43.06 & 43.06 \\
\hline \multirow{12}{*}{$\begin{array}{l}\text { Andreussi } \\
\text { water-air }\end{array}$} & Armand & 1.66 & 2.03 \\
\hline & Bankoff & 24.22 & 24.22 \\
\hline & Baroczy & 0.21 & 1.07 \\
\hline & Chen & -0.28 & 0.93 \\
\hline & Harrison & 4.26 & 4.31 \\
\hline & $\begin{array}{l}\text { Lockhart- } \\
\text { Martinelli }\end{array}$ & 1.97 & 2.01 \\
\hline & $\begin{array}{l}\text { Spedding, } \\
\text { Chen }\end{array}$ & 0.88 & 1.13 \\
\hline & Stomm & 89.35 & 89.35 \\
\hline & Thom & -3.74 & 3.74 \\
\hline & Turner, Wallis & 16.50 & 16.50 \\
\hline & Zivi & -0.43 & 2.07 \\
\hline & Zuber-Findlay & 12.11 & 12.11 \\
\hline
\end{tabular}


Tab. 2. Statistical evaluation of gas volume participation - contiuned

\begin{tabular}{|c|c|c|c|c|}
\hline \multirow[t]{2}{*}{ Data } & \multirow[t]{2}{*}{ Method } & \multicolumn{3}{|c|}{$\begin{array}{l}\text { Value of statistical } \\
\text { values }\end{array}$} \\
\hline & & $\delta R_{g} \%$ & $\left|\delta R_{g}\right|$ & $\%$ \\
\hline \multirow{12}{*}{$\begin{array}{l}\text { Tisyn } \\
\text { water-air }\end{array}$} & Armand & 23.41 & 23.53 & \\
\hline & Bankoff & 43.42 & 43.42 & \\
\hline & Baroczy & 54.57 & 54.57 & \\
\hline & Chen & -3.04 & 26.30 & \\
\hline & Harrison & 80.82 & 80.82 & \\
\hline & $\begin{array}{l}\text { Lockhart- } \\
\text { Martinelli }\end{array}$ & 36.48 & 36.48 & \\
\hline & $\begin{array}{l}\text { Spedding, } \\
\text { Chen }\end{array}$ & 32.71 & 33.49 & \\
\hline & Stomm & 36.38 & 36.38 & \\
\hline & Thom & 76.58 & 76.58 & \\
\hline & Turner, Wallis & 87.03 & 87.03 & \\
\hline & $\overline{\text { Zivi }}$ & 89.17 & 89.17 & \\
\hline & Zuber-Findlay & 39.03 & 39.03 & \\
\hline \multirow{12}{*}{$\begin{array}{l}\text { Tisyn } \\
\text { glycerin- air }\end{array}$} & Armand & 21.84 & 22.86 & \\
\hline & Bankoff & 43.40 & 43.40 & \\
\hline & Baroczy & 61.93 & 61.93 & \\
\hline & Chen & 4.83 & 27.03 & \\
\hline & Harrison & 81.45 & 81.45 & \\
\hline & $\begin{array}{l}\text { Lockhart- } \\
\text { Martinelli }\end{array}$ & 42.39 & 42.39 & \\
\hline & $\begin{array}{l}\text { Spedding, } \\
\text { Chen }\end{array}$ & 31.14 & 32.33 & \\
\hline & Stomm & 34.78 & 34.78 & \\
\hline & Thom & 82.47 & 82.47 & \\
\hline & Turner, Wallis & 88.81 & 88.81 & \\
\hline & $\overline{\text { Zivi }}$ & 89.89 & 89.89 & \\
\hline & Zuber-Findlay & 38.79 & 38.79 & \\
\hline \multirow{12}{*}{$\begin{array}{l}\text { Tisyn } \\
\text { ethanol-air }\end{array}$} & Armand & 21.77 & 22.43 & \\
\hline & Bankoff & 42.12 & 42.12 & \\
\hline & Baroczy & 54.57 & 54.57 & \\
\hline & Chen & -10.40 & 28.64 & \\
\hline & Harrison & 79.35 & 79.35 & \\
\hline & $\begin{array}{l}\text { Lockhart- } \\
\text { Martinelli }\end{array}$ & 31.85 & 33.53 & \\
\hline & $\begin{array}{l}\text { Spedding, } \\
\text { Chen }\end{array}$ & 30.00 & 31.94 & \\
\hline & Stomm & 78.05 & 78.05 & \\
\hline & Thom & 77.85 & 77.85 & \\
\hline & Turner, Wallis & 86.37 & 86.37 & \\
\hline & $\overline{Z i v i}$ & 88.71 & 88.71 & \\
\hline & Zuber-Findlay & 33.46 & 33.46 & \\
\hline
\end{tabular}

\begin{tabular}{|c|c|c|c|}
\hline \multirow{12}{*}{$\begin{array}{l}\text { Jasek } \\
\text { glycerin- air }\end{array}$} & Armand & 22.66 & 22.83 \\
\hline & Bankoff & 10.00 & 11.58 \\
\hline & Baroczy & 27.52 & 29.44 \\
\hline & Chen & 6.23 & 14.11 \\
\hline & Harrison & 33.03 & 34.77 \\
\hline & $\begin{array}{l}\text { Lockhart- } \\
\text { Martinelli }\end{array}$ & 20.24 & 22.27 \\
\hline & $\begin{array}{l}\text { Spedding, } \\
\text { Chen }\end{array}$ & 5.91 & 15.68 \\
\hline & Stomm & 66.21 & 66.21 \\
\hline & Thom & 27.14 & 32.89 \\
\hline & Turner, Wallis & 62.64 & 62.64 \\
\hline & $\overline{\text { Zivi }}$ & 29.56 & 34.93 \\
\hline & Zuber-Findlay & 8.61 & 13.89 \\
\hline
\end{tabular}

Figure 1 shows a graphic interpretation of comparisons of computational methods that were characterized by high accuracy of calculations. The best accuracy with experimental data is characterized by the Armand and Chen method (Figs. 2-3) for which approximately $70 \%$ of the points are within $\pm 30 \%$ of the absolute error. Both methods are characterized by high accuracy, because they are based on a slip model that best reflects the effect of viscosity changes and liquid density on the value of gas volume fraction. In addition, the Armand and Chen methods include interfacial slip, which contains the ratio of the actual velocities of the individual phases.

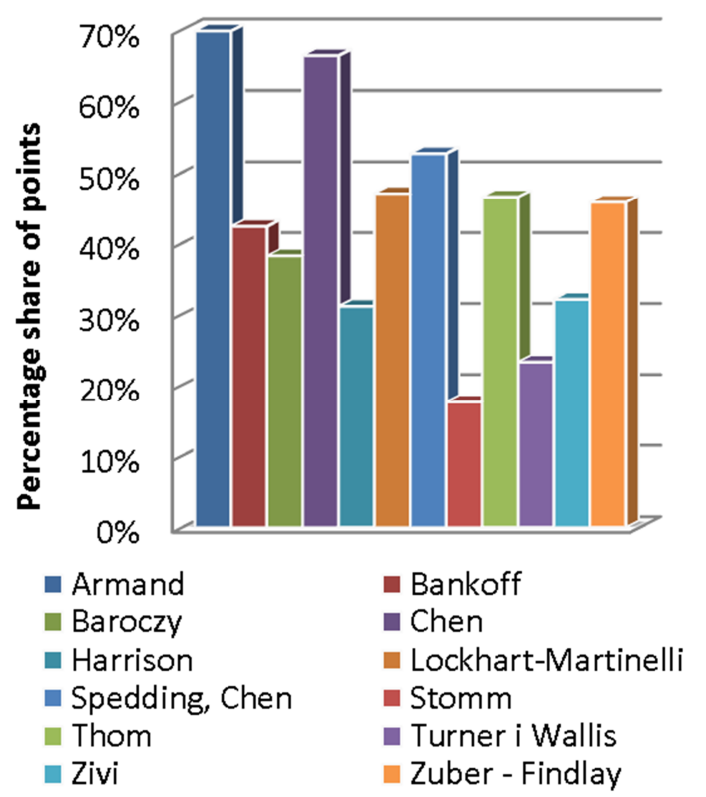

Fig. 1. Comparison of the accuracy of calculation methods for the volume fraction of gas in the falling flow of a two-phase mixture 
The impact of selected parameters on the calculation results (distribution of points) in the $R_{g, o b l}-R_{g, z m}$ system was evaluated. Graphical interpretations of selected calculation methods for gas volume fraction for various mixtures are shown in the Figures 2-13.

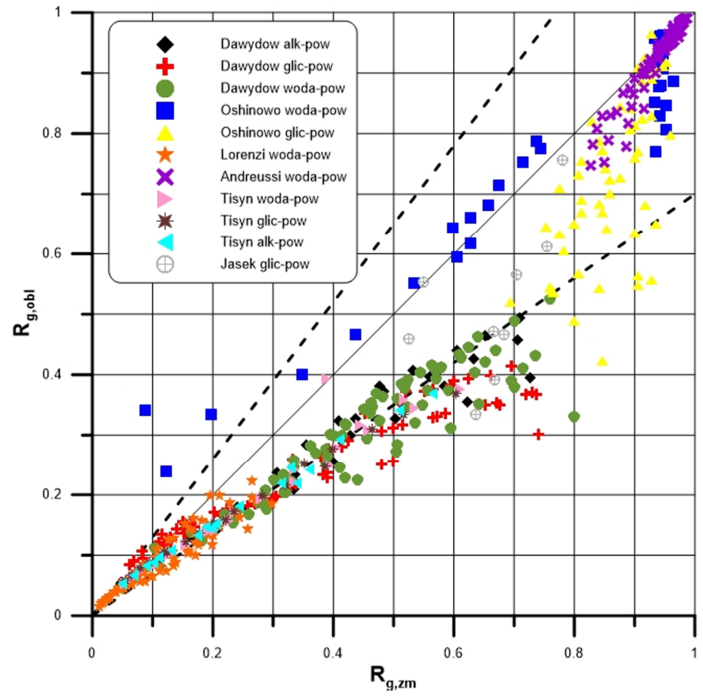

Fig. 2. Comparison of measured and calculated values of the gas volume fraction using the Armand method

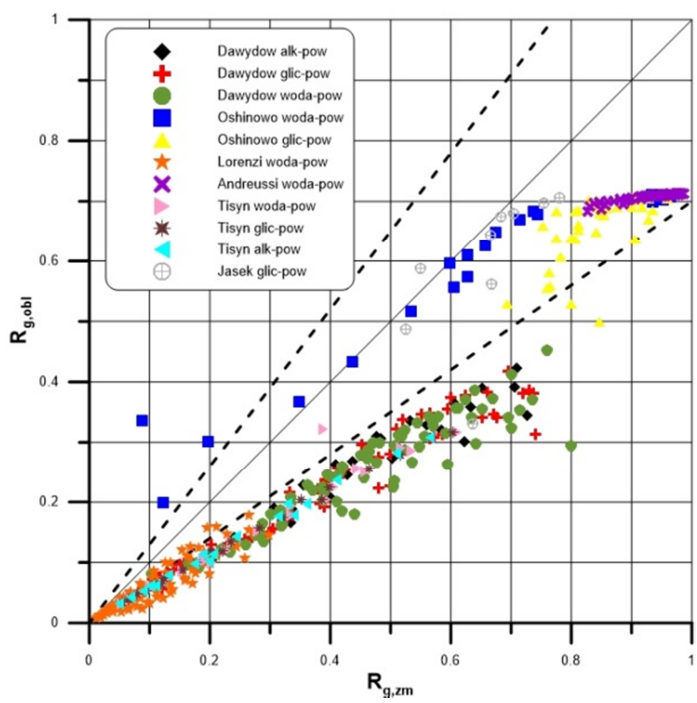

Fig. 3. Comparison of measured and calculated values of the gas volume fraction using the Bankoff method

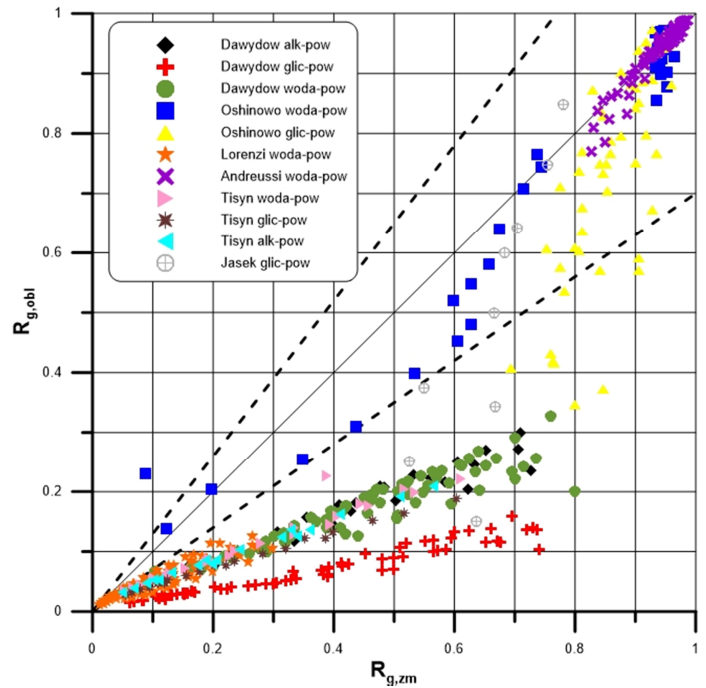

Fig. 4. Comparison of measured and calculated values of the gas volume fraction using the Baroczy method

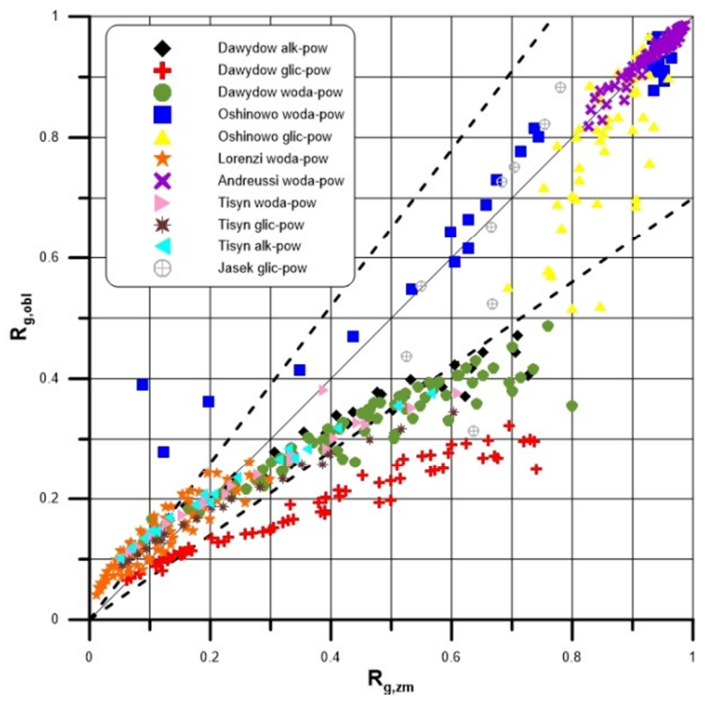

Fig. 5. Comparison of measured and calculated values of the gas volume fraction using the Chen method 


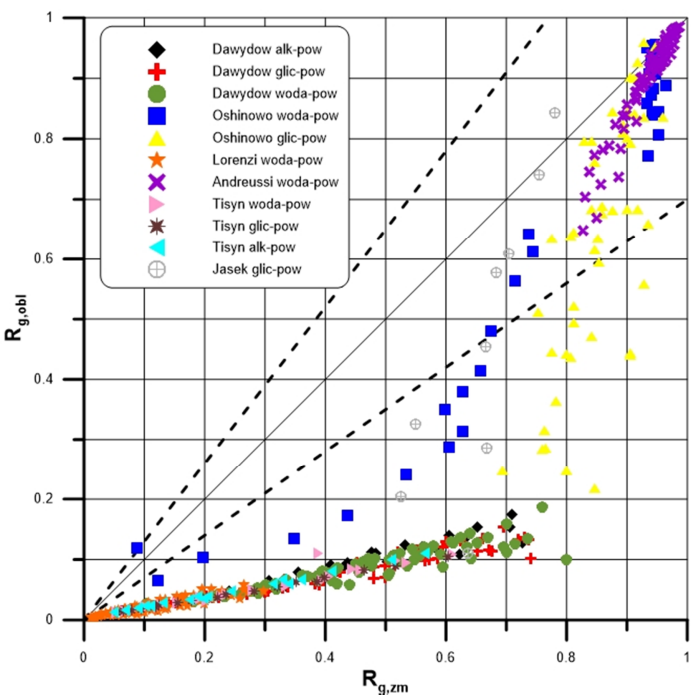

Fig. 6. Comparison of measured and calculated values of the gas volume fraction using the Harrison method

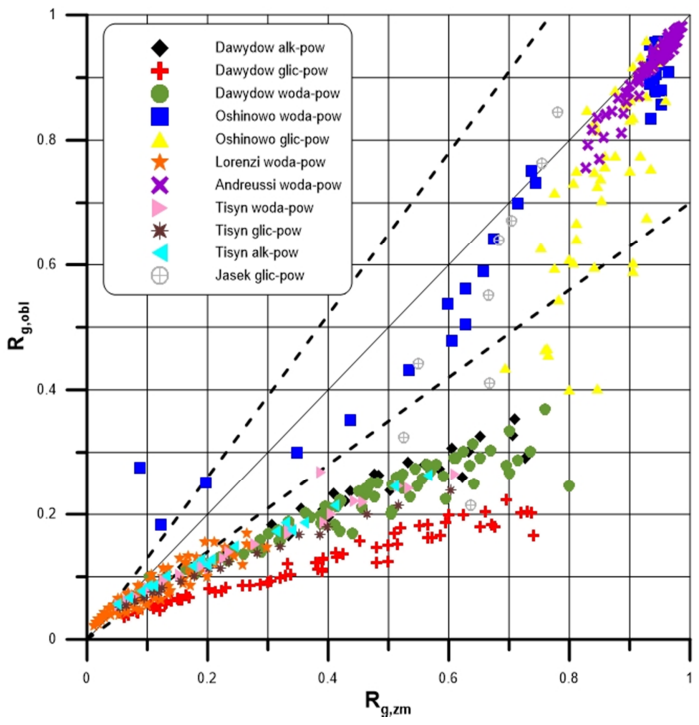

Fig. 7. Comparison of measured and calculated values of the gas volume fraction using the LockhartMartinelli method

\section{CONCLUSIONS}

Determining the volume fraction of gas in twophase flow as one of the three most important parameters is immensely important, so can be found so many calculation methods that have been proposed by different researchers. The authors of individual methods make their accuracy dependent on hydrodynamic parameters and ranges of applicability. Determining the volume fraction of gas is necessary to determine other parameters, including densities of a two-phase mixture that guarantee the correct design of equipment and apparatus, where two-phase flows are used.

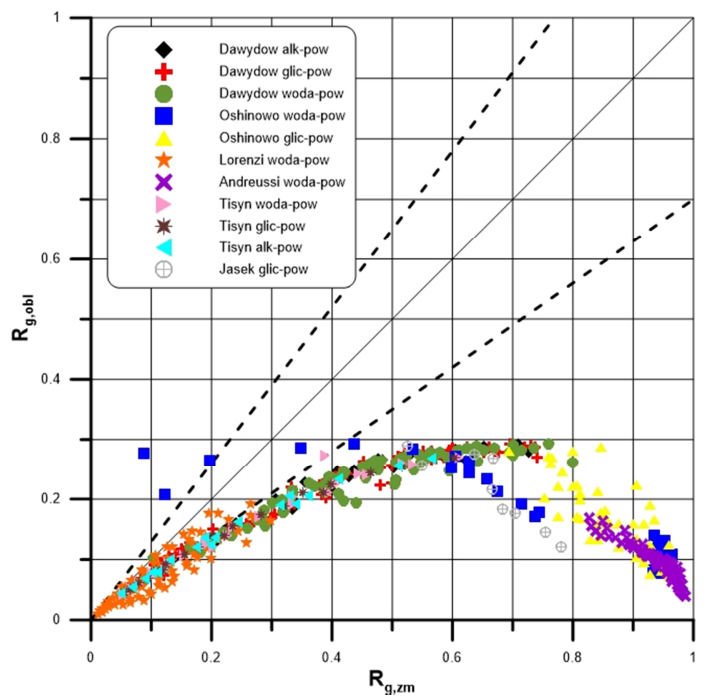

Fig. 8. Comparison of measured and calculated values of the gas volume fraction using the Stomm method

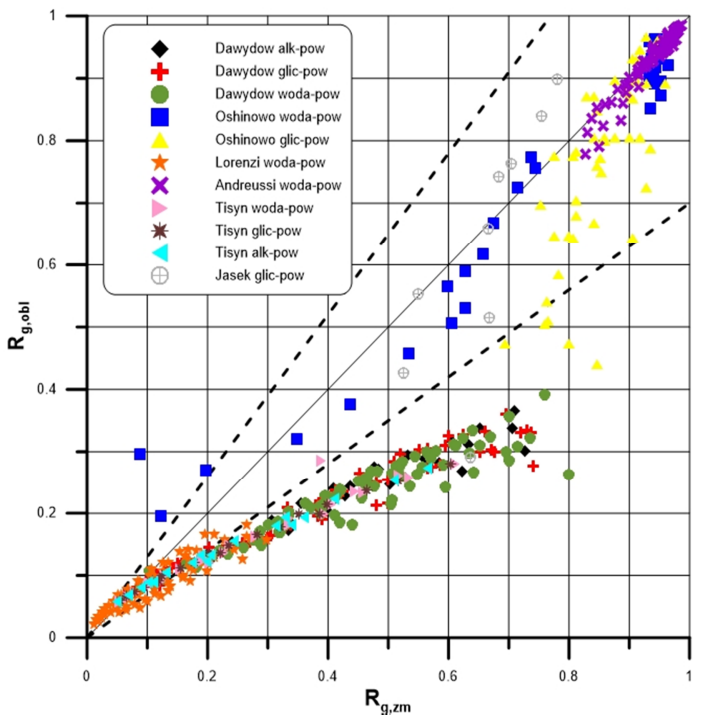

Fig. 9. Comparison of measured and calculated values of the gas volume fraction using the Spedding, Chen method

After analyzing the results of the volume fraction of gas using the methods proposed by the authors, it should be noted that in different ranges the volume fraction of gas does not coincide with the obtained experimental results. In a wide range of changes in flow parameters as well as physicochemical properties of two-phase mixture components, the highest accuracy of results is obtained using the methods of Armand and Chen, and therefore they can be recommended to calculate the gas volume fraction. 


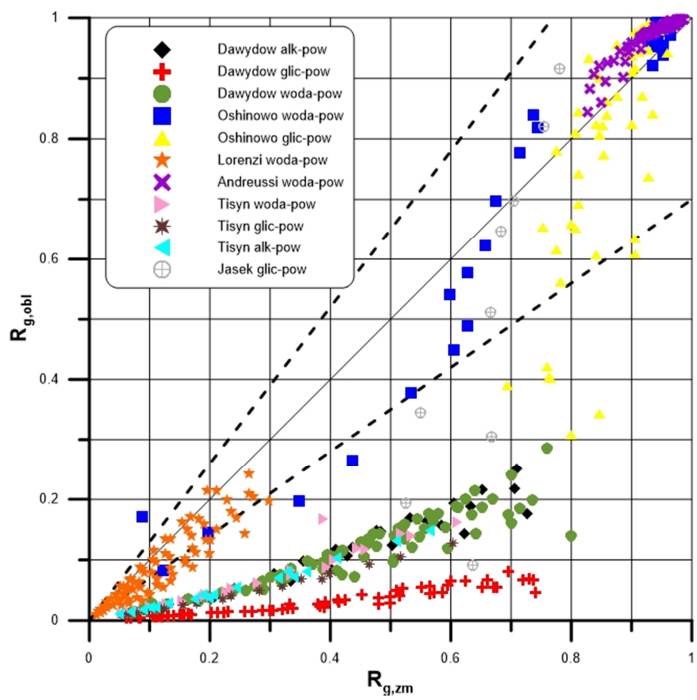

Fig. 10.Comparison of measured and calculated values of the gas volume fraction using the Thom method

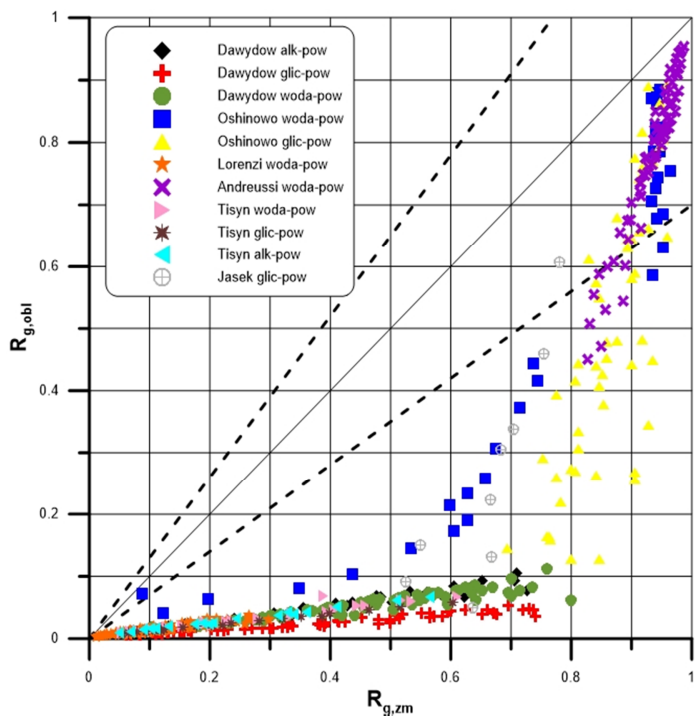

Fig. 11.Comparison of measured and calculated values of the gas volume fraction using the Turner an Wallis method

\section{References}

1. Bankoff S.G. (1960). A variable density single-fluid model for two-phase flow with particular reference to steam-water. Transactions ASME, Serie C, Vol. 82, No. 4, pp. 265-271.

2. Baroczy C.J. (1966). A systemic correlation for two phase pressure drop. Chemical Engineering Progress Symposium, Vol. 62, No. 64, pp.232-249.

3. Chen J.J. (1986). A further examination of void-fraction in annular two-phase flow. International Journal of Heat and Mass Transfer, Vol. 29, No. 11, pp.1760-1763.

4. Chen J.J.J., Spedding P.L. (1983). The analysis of holdup in horizontal two-phase gas-liquid flow. International Journal of Multiphase Flow, Vol. 9, No. 2, pp.147-159.

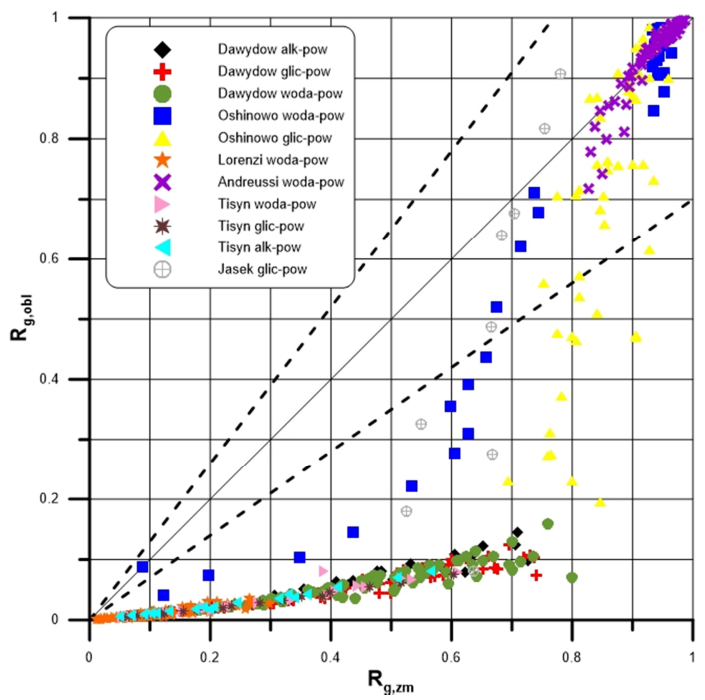

Fig. 12. Comparison of measured and calculated values of the gas volume fraction using the Zivi method

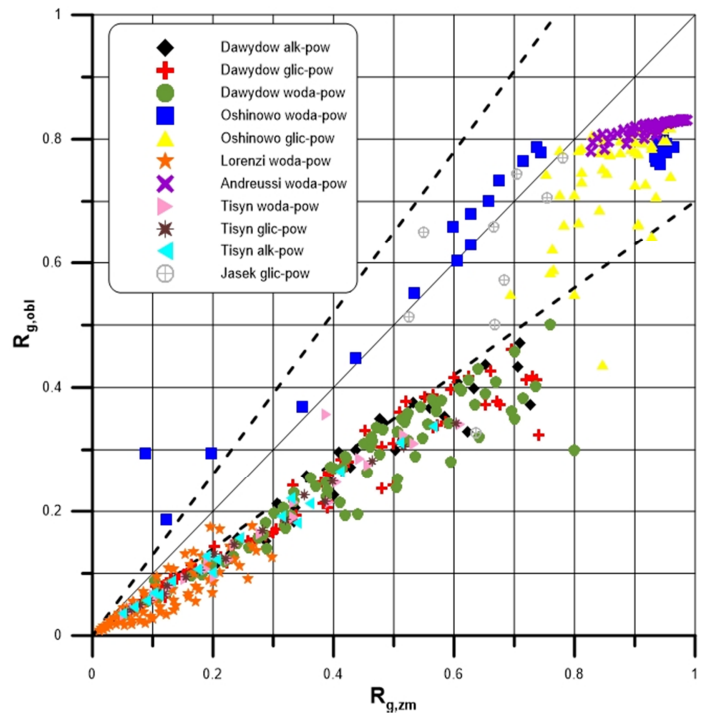

Fig. 13.Comparison of measured and calculated values of the gas volume fraction using the ZuberFindlay method

5. Czernek K. (2013). Hydrodynamiczne aspekty projektowania aparatów cienkowarstewkowych dla cieczy bardzo lepkich. Opole University of Technology, Opole, Poland.

6. Czernek K. (2003). The method of gas volume fraction calculation for two-phase gas-high viscosity liquid flow. Mechanika, Vol. 77, pp.15-23.

7. Czernek K., Filipczak G., Witczak S. (2006). Gas volume fraction in two-phase gas-liquid flow for very viscous liquid. Chemical Engineering and Equipment, Vol. 6s, pp. 46-47.

8. Czernek K., Filipczak G., Witczak S. (2008). Dynamics of annular two-phase flow of gas and a highly viscous liquid. Przemyst chemiczny, Vol. 87, No. 2, pp. 105-110.

9. Czernek K., Palińska K., Witczak S. (2006). Analysis of the calculation methods of gas volume fraction at two-phase flow very viscous liquid on the base of experimental data 
[in] VI Workshop "Modeling of multiphase flows in thermochemical systems. Numerical methods", Stawiska, Poland.

10. Czernek K., Witczak S. (2013). Non-invasive evaluation of wavy liquid film. Chemical and Process Engineering, Vol. 34, No. 2, pp. 241-252.

11. Dalkilic A.S., Laohalertdecha S., Wongwises S. (2008). Effect of void fraction models on the two-phase friction factor of R134a during condensation in vertical downward flow in a smooth tube. International Communications in Heat and Mass Transfer, Vol. 35, No. 8, pp. 921-927.

12. Dalkilic A.S., Wongwises S. (2010). Validation of void fraction models and correlations using a flow pattern transition mechanism model in relation to the identification of annular vertical down flow in-tube condensation of R134a. International Communications in Heat and Mass Transfer, Vol. 37, No. 7, pp. 827-834.

13. Delhaye J.M. (1984). Les divers modeles d'ecoulements diphasiques azliquide. Houille Blanche, Vol. 3-4, p.179-192.

14. Dziubiński M., Fidos H. (2003). Uogólnienie korelacji Lockharta-Martinellego dla określania udziału faz w przepływającej mieszaninie ciecz nienewtonowska-gaz, Chemical Engineering and Equipment, Vol. 5, p. 51.

15. Dziubiński M. (2005). Hydrodynamika przeptywu mieszanin dwufazowych ciecz-gaz. Łódz University of Technology, Łódź, Poland.

16. Harrison R.F. (1975). Methods for the analysis geothermal two-phase flow. ME thesis, University of Auckland, Auckland, New Zealand.

17. Katedra Inżynierii Procesowej (2004). Przeptywy dwufazowe gaz-ciecz. Bank danych doświadczalnych. Politechnika Opolska, Opole.

18. Lockhart R.W., Martinelli R.C. (1949). Proposed correlation of data for isothermal two-phase two-component flow in pipes. Chemical Engineering Progress, Vol. 45, No. 1, pp. 38-48.

19. Palińska K. (2006). Udziat objętościowy w przeptywie dwufazowym gaz-ciecz bardzo lepka. ME thesis, Opole University of Technology, Opole, Poland.

20. Spedding P.L., Chen J.J.J. (1984). Holdup in two phase flow. International Journal of Multiphase Flow, Vol. 10, No. 3, pp. 307-339.

21. Stomma Z. (1979). Two-phase flows-void fraction values determination. IBJ, Raport No. INR/1818/IX/R/A, Świerk, Poland.

22. Thom J.R.S. (1964). Prediction of pressure drop during forced circulation boiling of water. International Journal of Heat and Mass Transfer, Vol. 7, No. 7, pp. 709-724.

23. Turner, J.M., Wallis, G.B. (1965). The separate-cylinders model of two-phase flow. Thayer's School Eng., Dartmouth College, Hanover, NH, USA, Paper No. NYO-3114-6.

24. Ulbrich R. (1989). Identyfikacja przepływu dwufazowego gaz-ciecz. Zeszyty Naukowe WSI w Opolu, Mechanika, No. 32.

25. Troniewski L., Ulbrich R., Łukaszewicz S. (1982). Metody obliczania udziału objętościowego gazu przy przepływie dwufazowym. Zeszyty Naukowe WSI w Opolu, Mechanika, No. 16, p. 57.

26. Troniewski L., Witczak S., Czernek K. (2006). Hydrodynamics and heat transfer during two-phase gas-high viscous liquid flow in film reactor. Chemical and Process Engineering, Vol. 27, No. 4, pp. 1341-1359.

27. Witczak S., Czernek K. (2004). Hydrodynamics of high viscosity liquid and gas downflow in vertical pipes. Chemical Engineering and Equipment, Vol. 3s, pp. 176-177.
28. Woldesemayat M.A., Ghajar A.J. (2007). Comparison of void fraction correlations for different flow patterns in horizontal and upward inclined pipes. International Journal of Multiphase Flow, Vol. 33, No. 4, pp. 347-370.

\section{Biographical note}

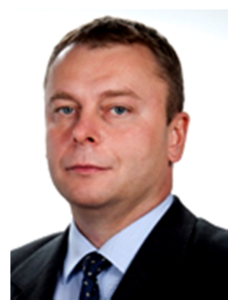

Krystian Czernek received his M.Sc. degree in Mechanical Engineering and next $\mathrm{Ph} . \mathrm{D}$ as well as D.Sc. degree from Opole University of Technology, in 1999, 2004 and 2014, respectively. Since 1999 he has been a researcher in the Faculty of Mechanical Engineering in the Department of Process Engineering at the Opole University of Technology, where currently he works as an associated professor. His scientific interests focus on research on multiphase flows and construction of thin-film apparatus as well as methods for identifying phenomena occurring during the flow of multiphase systems. He has participated 6 national research projects, presenting results of his work at 15 international and 28 national conferences, published more than 70 scientific papers in international and national journals, book chapters, as well as conference proceedings. $\mathrm{He}$ is also the author of 6 monographs.

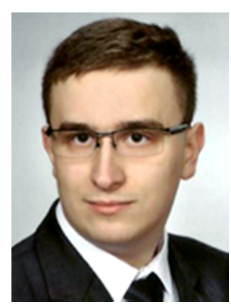

Patryk Okon is a graduate of the Opole University of Technology in the field of chemical engineering and process engineering of 1 st degree studies, as well as mechanics and machine building specialties, seconddegree industrial machinery and equipment. He graduated in 2017. He is a PhD student at the Department of Process Engineering at the Opole University of Technology. In doctoral research, he deals with the problems of multiphase flows, in particular two-phase, viscous gas and liquid flow in small diameter channels. He is the author of two scientific publications. 